\title{
Governing access to gold in Ghana: in-depth geopolitics on mining concessions
}

\author{
Sabine Luning and Robert J. Pijpers
}

\section{Introduction}

In 2011, while studying the relation between large-scale and small-scale gold mining in the western region of Ghana, we were invited to visit a concession where the Canadian mining company Keegan Resources was about to move from the stage of exploration to industrial mining. The CEO of the company, a geologist, was excited about the discovery that appeared to allow for this development: for a long time alluvial gold had been mined near the riverbed, but in 2006 Keegan found the source of this alluvial gold while constructing a road. This accidental find was followed by extensive exploration activities, which allowed Keegan to identify the exact location and contours of the ore body. During the visit, the geologist wanted to show us the hill that contained the ore body in its outcrop. On our walk uphill, several artisanal miners, both men and women, approached us, shouting and screaming while making angry gestures. They prevented us from accessing the area, clearly indicating that this hill belonged to them and underscoring that the company and artisanal miners were in competition over this particular deposit. After we explained our purpose and position, we were made to understand that we should go and see the chief of the village first, to ask permission to enter their mining area. Clearly, status positions and legitimation of claims were contested in this competition over mineral resources: the company may officially own the concession and mineral rights, but local artisanal miners consider their appropriation of this resource legitimate and see their chief as the appropriate authority.

However, the tensions over appropriation were not solely affected by challenges in the social arena as to who has authority to give or withhold access to resources. The geologist explained that the staff's excitement at finding the source of the alluvial gold in this outcrop had its downside: the geological situation is such that the ore can be targeted both by artisanal miners using artisanal methods and by large-scale industrial miners. Artisanal miners can easily access the ore by building horizontal tunnels at several points into the hill, as well as easily process the ore as weathering has made the material soft. According to the CEO of Keegan Resources, since this discovery, around 1,000 artisanal miners have left their alluvial sites near the riverbed to start digging uphill, and he stressed that gaining exclusive access to this primary source would be very difficult.

\footnotetext{
Sabine Luning is a senior lecturer at the Institute of Cultural Anthropology and Development Sociology, Leiden University. Her research focuses on economic anthropology, in particular the booming business of gold mining in West Africa. Email: SLuning@FSW.leidenuniv.nl

Robert J. Pijpers is a PhD candidate at the Department of Social Anthropology, University of Oslo. His work focuses on social and economic change, extractive industries and the micro-politics of resource governance in West Africa. Email: r.j.pijpers@sai.uio.no
} 
Two factors appear to play a key role in the challenges and competition over access to this ore body. First of all, given the history of artisanal mining and the way gold mining has been embedded in local practices of land use and structures of authority, Keegan Resources will never be in a position to fully exclude artisanal miners from 'their' concession. Working out some sort of arrangement in which artisanal miners' access will be confined will require the support of the local chiefs. Secondly, geology plays an important role in the way in which different groups may or may not have access to the resources: the way this particular ore body is located underground allows for extraction on different scales. Industrial and artisanal miners differ in their technical capabilities to access (parts of) specific ore bodies. Both socio-political aspects and geological features of ore bodies influence how companies and artisanal miners work out arrangements concerning access to and control of gold deposits at specific localities. The aim of this article is to foreground and analyse the interplay between politics and geology in forms of cohabitation between miners operating at different scales. We call this interplay in-depth geopolitics.

\section{Cohabitation: negotiating access and control}

The situation described above is typical of many places where gold mining occurs in Ghana, and in Africa more broadly. In most of the areas in which the national state has allocated permits to international companies - both junior exploration companies and major companies with productive gold mines - large-scale mining is taking place alongside other forms of land use, in particular gold mining at an artisanal scale. Mining companies are often relative newcomers on the scene, whereas artisanal gold mining and other forms of land use such as agriculture have a much longer history. Scholars (Hilson 2002a; Aubynn 2006; 2009) describe how mines can opt to forge partnerships with local small-scale miners, for example by allocating specific areas to artisanal miners, while declaring target areas for the company's industrial operations off limits for small-scale miners. Several gold mining companies describe their policies for dealing with such situations in terms of 'cohabitation' (see, for example, AGA 2010: 31). The cohabitation that is brought about shows interesting spatial intertwining around access points to mineral deposits, or 'ore bodies'. A major question concerns the power relations through which these arrangements have to be worked out. Jennings (1994) argues that, since mining companies are the legal and authorized owners, cohabitation is merely based on a voluntary agreement. Mining companies can choose to accept small mining operations on their concession and specify the conditions under which these can continue. Jennings is right that in terms of national law, large-scale miners have legal status while artisanal miners - in Ghana called galamsey - often lack such status. This legal/illegal divide is highly relevant for governance issues and can lead to uneven power relations in forms of cohabitation or to the dispossession of small-scale miners altogether (Hilson and Yakovleva 2007; Tschakert 2009).

Power configurations at mining sites may be more complex, however, as Emel et al. show (2011). They point out that in most African countries the state's authority to grant mining rights is based on a system in which the state is the ultimate owner of subsoil mineral wealth: the distinction between public and private coincides with the difference between subsurface and surface ownership. 
Furthermore, national sovereignty over mineral wealth - so-called subterranean sovereignty - has often been framed in opposition to foreign capital. The authors show, however, how the national ownership of subterranean resources may facilitate alliances between state and international companies at the expense of local groups' surface rights at mining sites, often limiting their access. Yet, they suggest, the way in which 'subterranean sovereignty' and 'layered rights' affect power relations between state authorities, companies and local communities must be studied empirically since 'sovereignty is negotiated at the level of the global-national scale, [but] it is territorialized at the local scale. Thus, we must also keep attuned to the ways in which local populations living in the spaces of extraction are constantly interrupting state-capital sovereignty projects' (Emel et al. 2011: 73).

In order to move away from a limited perspective on rights, Ribot and Peluso (2003) have suggested focusing on access rather than on (formal) property and entitlements. They define access as the ability to benefit from things. Sometimes one may have rights, but the means to benefit from these rights (such as capital or labour) are lacking. In that case one has property (the right to benefit) without access (the ability to benefit). In their theoretical frame they elaborate how technology, capital, markets, labour, knowledge, authority, identities and social relations more broadly influence access mechanisms; hence they talk about a 'web of access'. Moreover, they distinguish between 'access control' and 'access maintenance': the first concerns the ability to mediate the access of others; the second is about how one can safeguard access over something from which one takes benefits.

Since the publication of this work, different scholars have brought some of these insights to the study of allocation of land and resource exploitation in African societies. Sikor and Lund (2009) have shown how access mechanisms are affected by the exercise of power and authority. Current approaches underscore that, in Africa, access to land can only be understood in wider arenas of authorizers such as chiefs, ritual officiants, landowners and state authorities. As Lentz (2006: 1) argues for West Africa in general, land ownership is a complex bundle of socially and politically embedded rights related to specific groups of which membership can be contested and negotiated. Not surprisingly, mining companies seeking access to land become part and parcel of these local arenas in which access and authority are negotiated.

Local political dimensions affecting mining practices in Ghana have only recently started to be addressed, although conflicts between large-scale and artisanal mining have been studied for a longer period (Hilson 2002b; Andrew 2003; Hilson et al. 2007; Aubynn 2009). Standing and Hilson (2013) explore how chiefs benefit directly from formal arrangements for the redistribution of mineral wealth, and Geenen (2015) analyses mining concessions as sites of hybrid governance. Our article connects with this literature and shows how access to gold resources is entangled with the socio-political landscape at tangible mining sites. It does so, however, by adding an extra dimension to the political landscape of mining. So far, studies on mining in Africa have taken a two-dimensional, horizontal, perspective. The studies often focus on land use and analyse how large-scale and small-scale miners compete over the same surface area (Hilson 2002a; 2002b). However, they do not fully acknowledge that geological characteristics are key to how access to gold is organized. The spatial approach 
proposed here explicitly moves from a flat to a three-dimensional perspective: different miners work different parts of deposits located at different depths. We will show how 3D perspectives - that is, the knowledge of specific subterranean structures - play a major role in shaping interactions over access between miners. The embeddedness of 3D perspectives in the landscape of socio-political relations - in-depth geopolitics - is central to this article.

\section{In-depth geopolitics: from surface to underground}

Concessions for mineral or oil extraction have been portrayed mainly as contiguous spaces, Bridge (2009) argues, whereas in practice they are marked primarily by an agglomeration of access points and can be characterized as 'punctuated, discontinuous geographies of extraction [that] do not coincide well with notions of national territory' (ibid.: 46). Bridge builds on James Ferguson's critique (2005) of James Scott's (1998) focus on the nation state as territorial grid maker, in which he argues that in contemporary Africa mining companies are important organizers of space. Companies - oil companies serve as Ferguson's examples - carve out usable spaces to which their capital can 'hop', bypassing unusable spaces. He argues that the way in which companies secure spaces for mining - creating mining enclaves, for example - undermines the contiguous and bounded nature of national territories. Building upon this idea, Hannah Appel (2012: 439) shows what the 'hopping' of capital looks like at an oil site in Equatorial Guinea, describing 'how infrastructure becomes a key site through which oil and gas companies and Equatoguinean actors negotiate entanglement and disentanglement, responsibility and its abdication'. Both Ferguson (2005) and Appel (2012) show how the spatial organization of extraction is relevant to issues of sovereignty and governance, but they confine their view to the surface level. Bridge (2009) emphasizes the subsurface dimension of how capital 'hops' and 'lands' by paying attention to the ways in which operations tap into 'a netherworld of rocks and reservoirs'. The knowledge and techniques used to get access to underground wealth structure relations on the ground: they determine how sites are securitized, which patches are considered valuable, and which are dismissed as unusable.

The characteristics of access control and maintenance at specific mining concessions are strongly influenced by an interplay between three factors: (1) the stage of a mining operation (in particular the exploration and gold-producing mode); (2) the historical embeddedness of artisanal gold mining in local socio-political landscapes; and (3) the characteristics of the specific subterranean structures. It is this interplay that we term 'in-depth geopolitics'. Our approach builds on recent insights in the disciplines of geography and anthropology, which inform our rethinking of 'geopolitics'. Currently, those who use this term insist that attention should be given to conflicts playing out at different (spatial) scales and to power holders other than states (such as economic actors, including mining companies) (Cowen and Smith 2009). What we do in this article concurs with this alternative approach to geopolitics: we take mining concessions as sites for governance involving economic players (mining companies and artisanal miners) and political authorities positioned at national as well as local scales. But where we move beyond this approach is in the 'in-depth', 3D, aspect of our approach to 
geopolitics, which ties in with the current attention to materiality in anthropology. Following the pioneering work of Tsing (2005), Ferry (2005) and Ferry and Limbert (2008), Richardson and Weszkalnys (2014) demonstrate how social studies should pay attention to the characteristics of mineral matters and infrastructures of extraction. Such a focus on the entanglement of the material with the social has proved to be very valuable for the study of mining practices. Subterranean territory that is targeted for mineral extraction can be seen as 'socionatures' (Swyngedouw 1996; 2004; Gellert 2005): as ore bodies embedded in specific social and technical frames of possibilities and circumstances. Our study of 'in-depth geopolitics' builds on these scholarly developments. The article shows how ways of governing access to gold on mining concessions are informed by an intricate combination of social and natural factors: a socio-political field of relations anchored onto an underground of geological structures. In order to analyse these forms of governance, we look at two mining operations located in south-western Ghana: one at the exploratory stage and the other a large-scale producing mine. Before turning to our cases, however, we briefly reflect on our digging into geology.

\section{Anthropological digging into geological perspectives}

Anthropologists are aware of the problems of doing research in fields where they may lack knowledge of matters that require technical expertise. Whether such research concerns the anthropology of engineers (Latour 1987), financial experts (Ho 2009; Maurer 2005; Zaloom 2006) or geologists, it can raise access problems of different sorts. In order to develop an analytical eye for geological expertise, we carried out collective fieldwork in Ghana and visited the two concessions in the company of Henk Gewald, a retired geologist who previously worked for the mining company Anglo American. He was invaluable not only as an expert with whom we could discuss geology, but also as a co-interviewer. At Newmont, for example, Henk Gewald's presence made it possible to discuss geological specifics of the concession with company geologists. While looking at crosssections of underground ore bodies on computer screens, we gained key insights into the company's uses of geological knowledge in working out social arrangements of cohabitation with artisanal miners. The presence of an expert in geology in our research team allowed us to see how knowledge about the underground is a major factor in organizing access control and maintenance (Ribot and Peluso 2003). In order to appreciate how this knowledge was instrumental in working out arrangements of cohabitation, we briefly recapitulate basic distinctions used by geologists.

Drawing the location of gold in a cross-section, Henk Gewald illustrated how geologists portray the underground world of ore bodies as disembedded from social circumstances on the surface (Figure 1). In reports accessible to the public, however, socio-technical information relevant to extraction is abridged using the terms 'reserves' and 'resources'.

Geological 'deep time' consists of slow processes in which small amounts of gases and liquids separate and travel to more accommodating places (Gewald 2010). The pathways for these 'migrants' are the cracks (veins and fractures) in the system. Quartz, some iron minerals and, occasionally, gold may travel along 


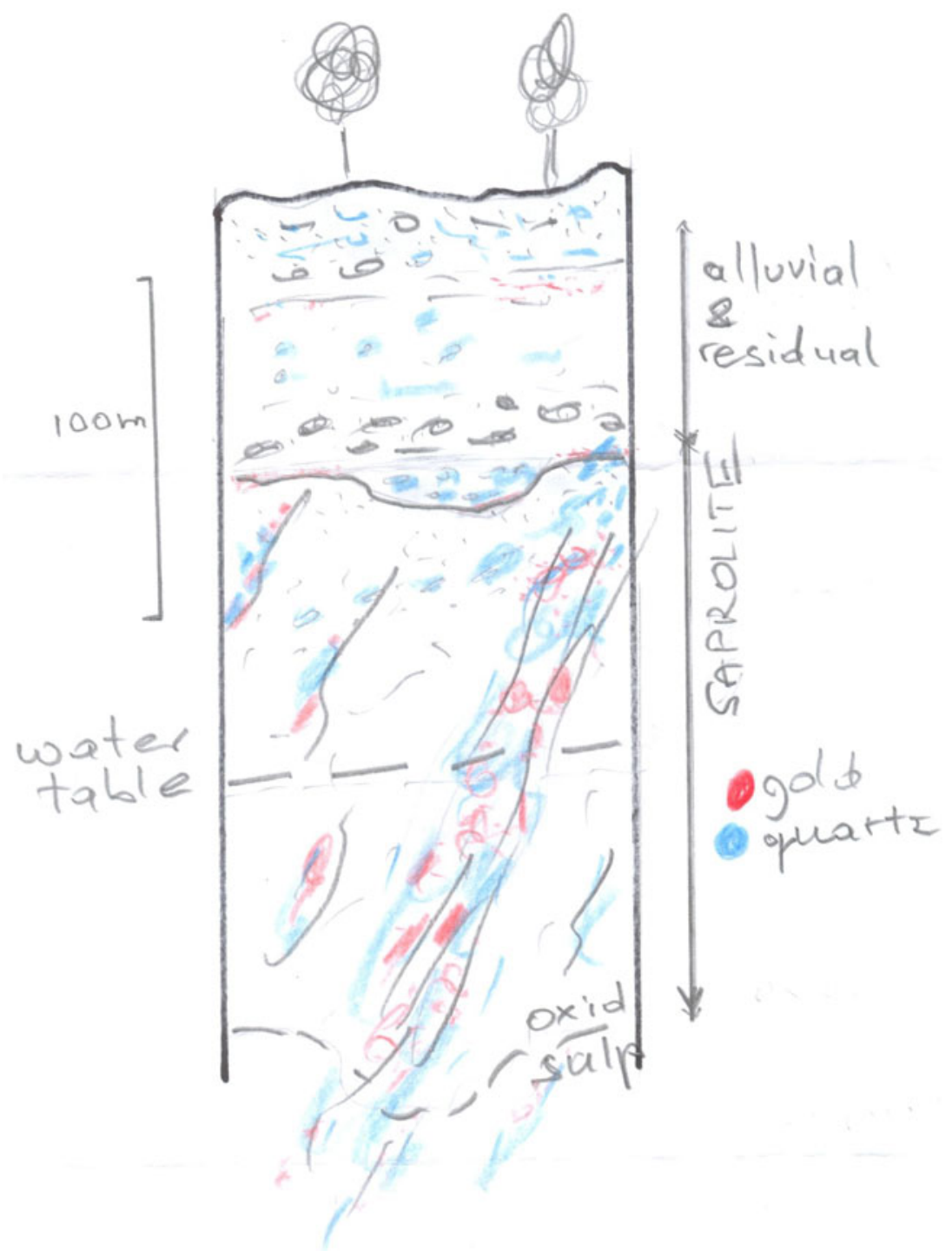

FIGURE 1 Cross-section depicting location of gold $(\mathrm{Au}){ }^{1}$

with such fluids. If stopped, this forms a 'deposit', which is called 'ore deposit' if it has sufficient economic value. Some parts of the ore are more easily extracted than others as a result of weathering, a process in which rocks, soils and minerals break

\footnotetext{
${ }^{1}$ We have chosen to use the original drawings done by Henk Gewald in the article.
} 
down through contact with air and water. This may happen in situ (by oxidation), but it also results from erosion where soil has been transported by water. Figure 1 shows an upper layer ('alluvial and residual') of subsurface material that has been moved, then a layer of rocks that have been weathered by oxidation ('saprolites'), and a bottom layer of 'fresh rock'. 2

In order to assess extractability, mining companies need to calculate whether and how ore deposits can be mined in a feasible way. Whereas a 'resource' and a 'reserve' are both considered potentially valuable deposits, a 'reserve' has the added characteristics of being legally, economically and technically feasible to extract. The distinction is used to guide decisions: is the mineral wealth located in a particular deposit valuable enough to invest in infrastructure? Do the social and political circumstances allow access to the ore? Parts of the deposit for which the answer is 'yes' are labelled as 'reserve'; other parts are classified as 'resource'. Since these social-technical circumstances may change over time, mining companies cannot base their decisions solely on theoretically informed $3 \mathrm{D}$ visualizations of space. Changes in the world market price of a specific mineral and/or political circumstances can turn resources into reserves and vice versa. As one of Keegan's exploration geologists told us: 'With gold at US\$2,000 an ounce, ${ }^{3}$ the whole of Ghana is going to be turned over; at $\$ 250$ all projects go into mothballs.' Moreover, social circumstances and political factors play a major role in reclassifying 'ore' as either reserve or resource, and occasionally even stop projects completely (Welker 2014: 53; Sosa 2012: 204-5). The notions 'reserve' and 'resource' serve to classify ore bodies as socionatures, a combination of social and natural factors. They force mining companies to assess the specific circumstances of the locality in which they would like to extract the ore.

In Ghana, the underground wealth is situated in social fields marked by a long history of artisanal mining and a specific political arena. While both companies in our study are legally the concession owners, in certain local settings the legal status attributed by the state is not the all-determining factor. In order to get at the ore, companies need to insert themselves into the already existing local social field: they need to engage in a politics of cohabitation by finding out how their own goals and capabilities for exploring and/or mining can be matched to the specifics of the local mining situation and political arena. For the two case studies, our analysis of in-depth geopolitics shows how 3D knowledge about ore bodies can be instrumental for formulating governance strategies, in which knowledge of the $2 \mathrm{D}$ social field is merged with a $3 \mathrm{D}$ perspective on ore. This combined knowledge serves not only to identify where competition over ore is to be expected, or which parts of ore bodies can be accessed only by industrial mining technology, but also what kind of cohabitation between large-scale and small-scale miners may be possible.

\footnotetext{
${ }^{2}$ Alluvial gold is 'free gold'; it is relatively easy to access because it is not contained in rocks, while gold that is 'locked up' needs to be liberated by crushing the gold material, and thus requires more technically advanced approaches.

${ }^{3} 1$ ounce $=$ approximately 28.35 grams.
} 


\section{Keegan Resources: competing over an outcrop?}

At the time of field research in January 2011, the Canadian 'junior' Keegan Resources $^{4}$ was developing an exploration concession in a rural area south-west of Kumasi. Keegan originated as a project of a group of friends from Vancouver, where they employed about ten staff. In Ghana, they employed fifteen to twenty expat staff and 150 to 200 Ghanaian employees, of which a good number came from communities surrounding their concession. Keegan's operation was considered to be fragile in terms of both its financial security on the market and the social setting in which it had to operate.

Keegan, as an exploration company, was small in size and had limited physical visibility; it employed a small number of staff and its camp at the project site consisted of only a few houses for lodging, a small canteen, some offices and a space to store and analyse core samples. Unlike big mining companies, facilities at the compound were limited and in the evenings staff members occasionally went to the neighbouring village to get a cold drink. The operations of the company in the concession area appeared small, due to the specific technical stage of exploration. A few drills were on-site, trying to map out the ore body, and there was a zone for metallurgical test work. A security system had been put in place but was rather limited: the compound was barely fenced and the concession not surveyed by a private security force. For its geopolitics, Keegan relied first of all on the police, and thus on the Ghanaian state. In a relatively remote area, with little state presence, this created a challenging situation where securing the company's rights as concession owner involved long and ongoing negotiations with the local village chief. The geopolitics in the 2D social field made the company dependent upon an assemblage of actors, some associated with the state, others with local authority structures.

The fragility of the operation, in terms of its scale, went hand in hand with a tense social situation that Keegan 'inherited' from its predecessor, the Canadian gold producer Bonte Gold Mines. Bonte, which had mined the alluvial deposits in the riverbeds of the concession from 1994 to 2004, was liquidated on 31 March 2004, following the results of cases filed against the company by shareholders and creditors. It left without rehabilitating the environment and failed to pay wages to workers or compensation to farmers (Campbell 2011)..$^{5}$ According to Keegan's employees and management, the strained situation created by Bonte affected the way in which Keegan Resources was able to start its operations. Bonte's legacy shows that not only do actions of mining companies at the early stages of their own operation affect long-term relations with surrounding artisanal miners (Teschner 2013), but the actions of predecessors also have a significant impact on the wider contemporary social arena in which mining companies must operate.

Keegan's social setting was also strongly shaped by the current presence of artisanal miners in the concession area. Scholars have shown that companies and artisanal miners draw upon each other's knowledge to explore gold deposits.

\footnotetext{
${ }^{4}$ In February 2013, Keegan Resources renamed the company as Asanko Gold, a change that underscores the centrality of Ghana for the company's operation and also marks its transformation from an advanced stage exploration and development company to a significant gold producer. See <http://www.asanko.com>.

${ }^{5}$ See also articles and press releases at $<\mathrm{http}: / /$ www.infomine.com $>,<$ https://www.modernghana. com>, <https://www.ghanaweb.com>, and the National Coalition on Mining Ghana.
} 
Dumett (1998), for example, shows that the Wassa Gold Company, which operated in Ghana in the late 1800 s, had few means to find gold other than searching for abandoned artisanal sites. Nowadays, too, foreign companies often need the knowledge of artisanal miners to lead them to productive sites (Luning 2014). At the same time, artisanal miners closely observe the methods of new companies (sometimes as employees) and, where possible, use these in their own operations (Luning et al. 2014). Similar processes took place in Keegan's concession, where companyartisan interactions could almost be characterized as forms of espionage. The CEO of Keegan explained to us that artisanal miners sometimes read companies' websites to explore places to mine. But the company itself also follows the artisanal miners; as the CEO stated: 'When we see where they are digging, we go drilling. When they see us drilling, they go digging.' In order to understand how skirmishes over forms of cohabitation between Keegan and artisanal miners were shaped by both the legacy of a previous gold-mining company and the history of artisanal mining in the concession, we need to apply a 3D geological perspective.

Keegan's main target, the source of the alluvial gold that Bonte and artisanal miners mined previously, appeared to be almost vertically located in a hill with a clear exit point to the surface (Figure 2), called the outcrop. As we describe in the introduction, in this geological situation both artisanal miners (galamsey) using artisanal methods and companies using industrial means can target the ore. The fact that this ore body is suitable for different scales of mining gave rise to an edgy situation in which multiple stakeholders (Keegan Resources, local communities and 'external' galamsey) expressed an interest and tried to claim and control access to the deposit. The in-depth geopolitics was strongly influenced by this potential competition over the ore, which made arrangements for cohabitation precarious and full of tension.

The incident described in the introduction shows the public contestation of the company's access to this part of the concession. The challenges were not limited to competition over resources, but also concerned recognition of status positions and legitimation of claims: the company may officially own the concession and mineral rights, but local artisanal miners consider their appropriation of this resource legitimate and see their chief as the appropriate authority.

Being embedded in this social arena, Keegan Resources was not in a position to exclude artisanal miners from its concession. On the contrary, its only hope was to work out some form of compromise in which it would try to regulate and confine artisanal miners' access to the concession. Its aim was to maintain sole access to the primary resource, but in exchange it accepted - on certain conditions - that artisanal miners would continue to mine the alluvial deposits in the riverbed, a strategy that, as noted earlier, is not uncommon (Hilson 2002a: 72). Miners originating from communities in the vicinity who were using artisanal methods were tolerated, but outsiders coming with machines were not. In order to work out such arrangements, staff of the company acknowledged their dependence on the local chiefs. In the company's office we were shown maps in which boundaries of stool lands of chiefs ${ }^{6}$ were superimposed upon geological information concerning the area. Collaboration with the chiefs was

\footnotetext{
${ }^{6}$ In the south of Ghana, the stool is the symbolic object associated with chieftaincy. In colonial times, chiefdoms became organized as territorial units. Ever since, stool lands have been formally recognized by the state and are governed by chiefs (Firmin-Sellers 1995).
} 


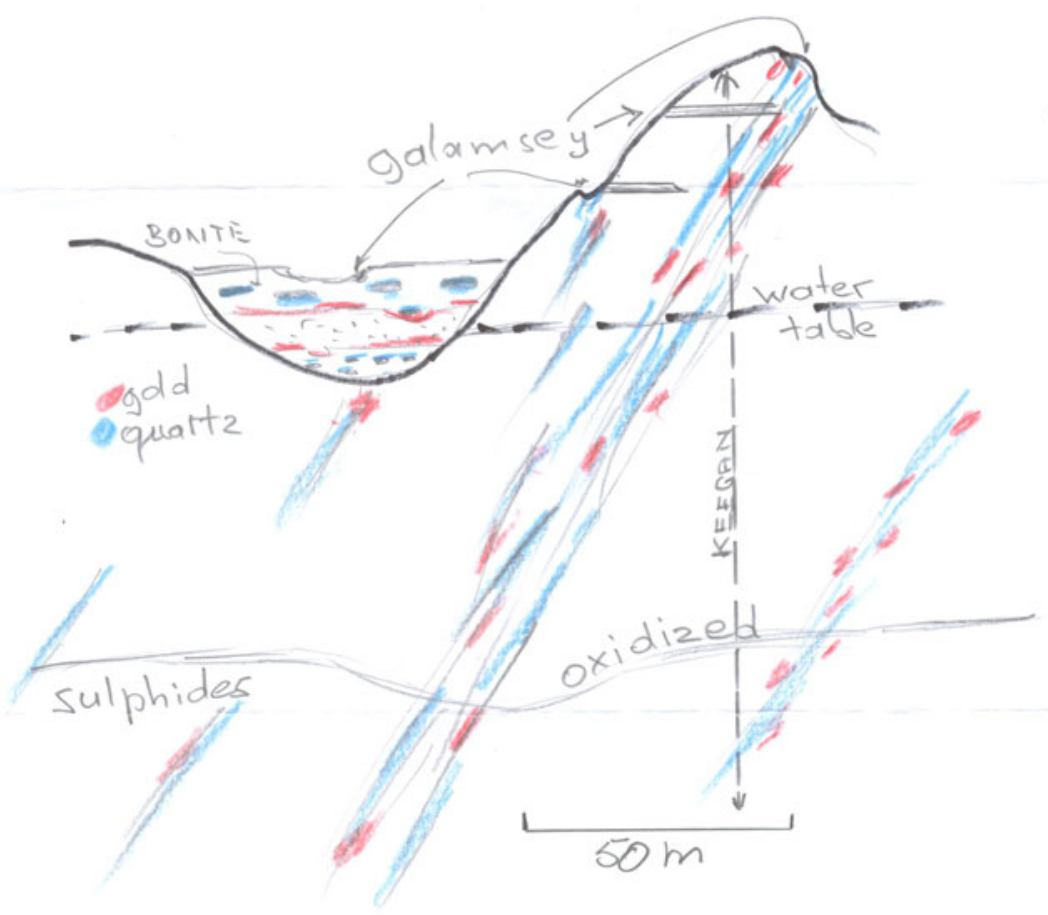

FIGURE 2 Keegan's geological situation.

made more problematic because some of them were pushing to re-mine Bonte's former area with excavators, so we were told. Even though Keegan was not interested in mining this area itself, it wanted to prevent 'foreigners' with machines from getting access to the riverbed, since doing so would open the door to the whole of the Ghanaian galamsey world: 'We just want traditional ways of mining and local people,' they argued. At the time of our research, we could not confirm whether the chiefs were indeed persuaded to collaborate with the company on these terms, but the case shows their key position in negotiating cohabitation.

The example clearly illustrates the merits of attending to in-depth geopolitics. For governing access to gold, the company depended on the chiefs as a consequence of the 3D geology, an ore deposit that created direct competition over access, and the 2D social field in the area. Being a small exploration company, with limited possibilities to enforce its mineral rights, the company sought to negotiate ways of 'confined' cohabitation, limiting: (1) which area could be accessed; (2) which groups could get access; and (3) which techniques would be allowed. In order to realize these limitations, the company 'played the card' of tradition and autochthony (Ceuppens and Geschiere 2005; Geschiere 2009). In other words, it was willing to allow a key role for the chiefs and the local population, who claimed access based on property rights and autochthony, at the expense of 'foreign' galamsey (from elsewhere in Ghana), who would be more difficult to control and could access the ore in the hill on a larger scale with their excavators. 


\section{Newmont: sharing a golden table?}

Newmont Mining Company is a large-scale gold-producing company with operations in the US, South America, Africa, Indonesia and Australia (Newmont 2009). Newmont's mine in Ghana is located in the rural area of the Brong Ahafo region in Western Ghana, not far from the urban centre of Sunyani. At the start of mining operations in 2006, the Ahafo mine processed ore from seven major pits, extending along a 40 kilometre strike (Hilson 2011: 10935), with substantial infrastructure, such as large mining equipment and roads. Here we find the typical spatial arrangement for a large-scale producing mine: an area with offices, restaurants, the processing plant and the central open pit, which are secluded and heavily securitized by a private security service. This part of the concession resembles the enclaved mining zones described by Ferguson (2005), Appel (2012) and MacEachern (2010). Even though this secluded area is only a small part of the concession as a whole, it dominates the local landscape. An extensive corporate social responsibility (CSR) programme with a large variety of community activities (Newmont 2005; 2009) adds to the company's visibility. The size of the operation and its visibility, typical for the production stage, affected the claims and expectations entailed in company-community relations.

Several studies describe how the Ahafo mine came into the hands of Newmont as part of the takeover of Normandy, an Australian gold-mining company, in 2002 (Hilson 2011; Welker 2014). Normandy had done no more than explore the area; no efforts had been made to build a mine, nor had there been any attempts to set up a CSR programme. When Newmont started its mining operations in 2006, the company initiated a CSR programme from scratch: in contrast to the case of Keegan, the company was not burdened by older legacies of tensions and promises. The Ahafo mine was seen by Newmont's CSR staff as a flagship case where CSR could be tailored exactly as it should be (Welker 2014: 35) and where Newmont would be a 'good company', working hard to gain its licence to operate (ibid: :54-5). This was all the more urgent at the Ahafo mine, given the social field in which chiefs were dominant. Kapelus (2009: 100) describes the company's dependence on traditional power holders at the expense of local government officials, and Hilson (2007: 51) details the pitfalls associated with representation of 'the local community'.

As in the case of Keegan, the area where Newmont operates has a long history of artisanal gold mining. According to Griffis et al. (2002: 184), the Gold Coast Geological Survey outlined the broad-scale geology of the area and noted old alluvial workings in the Kenyase area. Indeed, one of the striking features of the present situation is the prominence of artisanal miners on Newmont's mining concession. However, artisanal mining is barely mentioned in reports on community relationships. Although Newmont's Community Relationships Review (2009) acknowledges the historical presence of artisanal mining, Kapelus's (2009)

\footnotetext{
${ }^{7}$ Hilson (2011) acknowledges that this has had positive effects, but also points out that it led the company to formulate the CSR in an insulated manner, depending primarily on its own best practices, ICMM (International Council on Mining and Metals) standards and consultants, rather than on strong ties with and inputs from the community.
} 
in-depth narrative on Newmont's Ahafo mine gives it no mention, indicating that artisanal mining has never been an explicit topic for company policies.

During our fieldwork, the question did arise of how Newmont negotiates the presence of artisanal miners and their access to the deposits. Whereas staff members in charge of public and community relations told us a lot about CSR and company-community relations, they remained relatively silent on artisanal mining. Our conversations with geologists, however, raised interesting perspectives on how the company tried to work out forms of cohabitation with artisanal miners. Newmont tolerates these artisanal miners, a strategy that is informed by 'in-depth geopolitics': the socio-political structures as well as the geological characteristics of the underground area.

The artisanal miners, whose major operation concentrated on a site called Sikamina, meaning 'the pit of money', ran relatively large operations that used different kinds of machines and generated substantial revenues. The geologists showed us a 3D perspective on industrial extraction, as well as how this could be carried out in the social field of artisanal mining. We were presented with a cross-section to illustrate the specific structure of the way gold is positioned underground, and how - given such a 3D perspective - artisanal and industrial mining could cohabit. As we will demonstrate, the in-depth geopolitics of the setting allows for a solution in which the area of Sikamina is currently an artisanal site, even though Newmont proposes a new open pit in that area to be mined in the future.

Whereas Keegan's ore body was positioned vertically in a hill, in Newmont's Sikamina gold is positioned in multiple horizontal 'tables', as indicated in Figure 3. The water level is located between the first and the second table. This geological specificity leads to a situation in which both artisanal miners and the company have access to, and are partly in competition over, parts of the deposit. How could this social field of friction result in a scenario for feasible cohabitation? Let us first describe the current situation, in which only artisanal miners are digging for ore.

During our visit to Sikamina, a committee in charge of governing this artisanal mining site hosted us. The chairman belonged to one of the landowning families, and other members had been chosen because of their experience and expertise as gold miners. The committee explained that, before the area became a mining site, the landowners had been cocoa farmers. Three years ago they began renting the area to miners, which they expected to provide more money than Newmont's compensation for cocoa trees. Access to the gold was secured by combining property, the landowners, with ability, the miners (Ribot and Peluso 2003). Subsequently, as we will see later, access to the deposit also had to be negotiated with the concession owner, Newmont.

After introductions, we were given permission to enter the site. The area consisted of a large number of ghettos (see Figure 4): distinct spaces where 'gangs' run underground mining operations. Revenues are based on the amount of bags of ore produced and are shared on a weekly basis between all people involved in the operation. These typically include the committee, the landowner, the plant owner (who provides electricity), the labourers, the financier, the ghetto owner, and contractors (who provide the jackhammer, for example). Interestingly, the surface level of the ghetto - with a main shaft at the centre does not reflect the layout of the underground area. From the vertical shaft, going down to around 50 metres, the operation extends into horizontal 'drives'. 


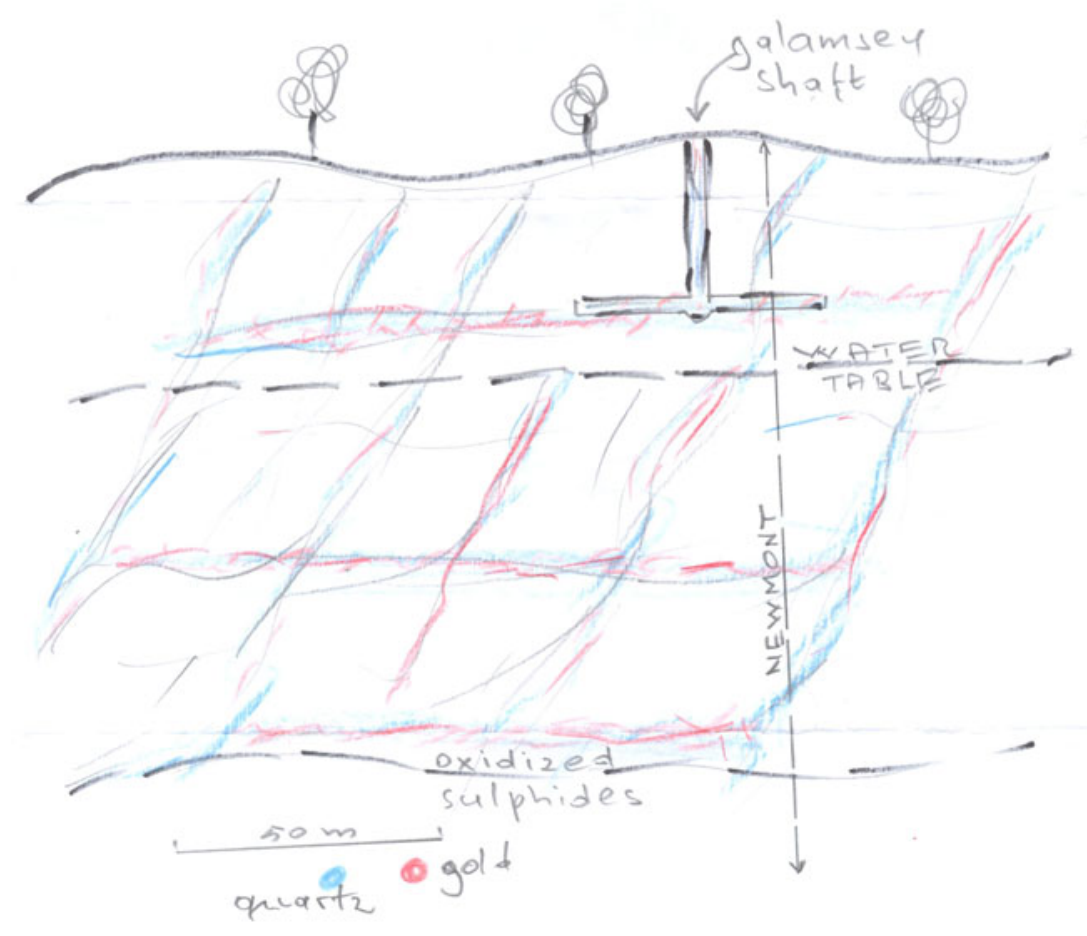

FIGURE 3 Newmont's geological situation.

In each drive, work teams consisting of watchmen, people with chisels, hammers and carriers, and occasionally someone with a jackhammer, try to extend the 'face' (the far end) of the drive as quickly as possible. Neighbouring ghettos may cross paths underground, and conflicts can arise. In such cases, the committee is called upon to assess and resolve the issue.

Although Newmont is the official owner of the concession, the artisanal site within its concession is well and independently organized: a clear governing system with accepted authorities had been established over the years. Moreover, miners in this area perceived it as their right to mine there; the fact that Newmont accepted their presence was not seen as a gift, but as the confirmation of their rights. Although Newmont did not necessarily share this perception, it did allow the artisanal miners to continue mining. The reasons for this are both geological and socio-political.

First of all, the artisanal mining operations in 'the pit of money' target the first table of gold, which is situated above the water table. As one of Newmont's geologists explained to us, Newmont uses the water level as the natural barrier for artisanal mining. Although artisanal miners are able to go relatively deep with simple methods, it would be too difficult and expensive for them to pass the natural water level. Once the artisanal miners have mined the first table of gold and reached the water level, they have to abandon the area. At this point, Newmont takes over and develops their pit. 


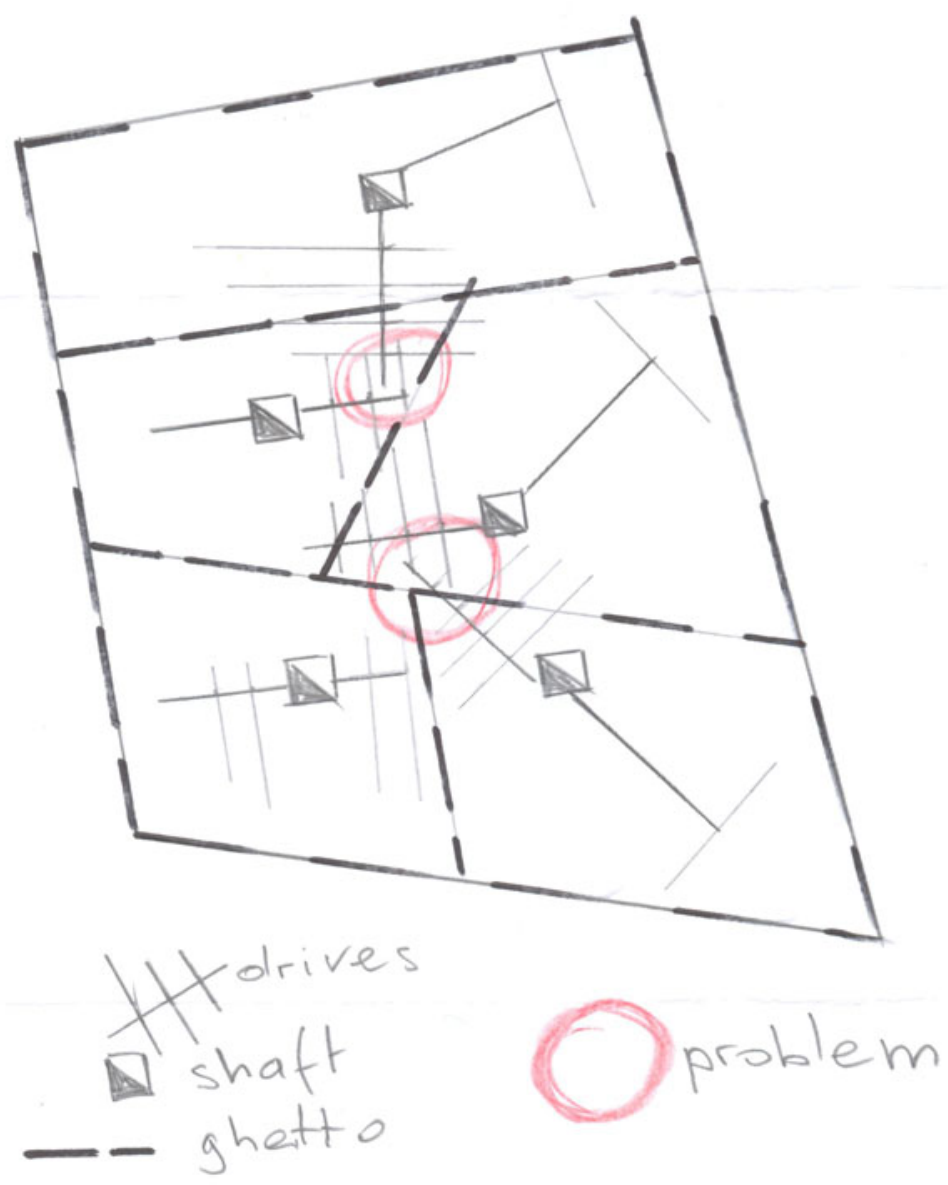

FIGURE 4 Ghettos at Sikamina.

Secondly, Newmont operates in a specific social and political landscape. The organization of the mining site confirms the importance of local authorities (Newmont 2009; Hilson 2007; 2011) and land use structures: local authorities and gold miners team up in governing the site. Newmont's strategy to 'give' part of the ore to artisanal miners is not so much based on generosity, but born out of necessity. Even though this company is a major transnational corporation and has the legal title to the concession, on the ground it is faced with a social field of land users and local authorities that restricts the company's options for organizing its operations. Newmont knows that, in the twenty-first century, it cannot get rid of artisanal mining. This is the result not just of alliances between chiefs, landowners and artisanal miners, but also of converging interests between the local population and national politicians. As Newmont's senior geologist explained: 'The company cannot easily ask the government to remove all these people, because they represent 10,000 votes.' Moreover, considering the artisanal 
miners' determination and conviction that they have the right to mine, forbidding artisanal mining would create serious tensions in the area and therefore might influence Newmont's social licence to operate. ${ }^{8}$ If it were not for the water level serving as a natural barrier, the tensions around the mine and the competition for its ore would be much more intense. In this case, the in-depth geopolitics that shapes negotiations over access forces Newmont to accept cohabitation in the present. However, this is only temporary since the geological conditions promise the company the prospect of exclusive access in the near future.

\section{Comparison of two cases}

This article seeks to contribute to a comparative approach to extraction practices, involving both fossil fuels and minerals, such as gold, by adopting a 3D perspective. We have analysed the in-depth geopolitics of two gold operations in terms of three characteristics: (1) the type of large-scale mining operation; (2) the local history of gold mining and the socio-political landscape; and (3) the geological layout. The combination of these factors influences the ways in which access to gold is governed and negotiated in specific politics of cohabitation.

Typically, Ghanaian gold concessions for both exploration companies (known as 'juniors') and for gold-producing companies (known as 'majors') encompass substantial zones marked by the presence of villages, agricultural lands and artisanal mining sites. This forces companies to work out arrangements of cohabitation. In existing studies of the governance of extraction, in which oil features prominently, the enclaved nature of extractive practices is emphasized. Ferguson discusses the concept of 'extractive enclaving' (2005: 378) and Bridge (2009) argues that extraction produces classic enclave economies that are deeply integrated into the global economy but also fragmented from national space. In this article we have sought to explore a broader range of the spatial arrangements characteristic of extractive practices, by looking at a 'minor' exploration and a 'major' production operation.

In the first case, the exploration company of Keegan Resources, the notion of 'enclave' seems to be altogether at odds with the actual spatial arrangement. Instead, we found that 'intertwinement' is a core characteristic of the spatial arrangement. Even in the case of Newmont, the major producing company, the notion of enclave must be nuanced. We see that the company securitizes and closes off patches within the concession where its capital (machines, processing plant and staff) and access points to the deposit (Bridge 2009) are located, but other parts of the concession may be 'left' to artisanal miners.

The case studies show that, for gold mining, the notion of 'enclave' may be too rigid, leaving the question of how different mining companies manage to govern their concession in a specific context under-analysed. The two cases foreground how differences in operations are part of the in-depth geopolitics that affects modalities of 'governing extraction'. The attention of Emel et al. (2011) to 'subterranean sovereignty' urges researchers to analyse how local politics interrupt the

\footnotetext{
${ }^{8}$ For more references to the notion of a 'social licence to operate', see, for example, Bridge (2009), Prno and Slocombe (2012) and Baba and Raufflet (2014).
} 
state-company sovereignty process. The cases we have presented speak directly to that research agenda. The concessions that Keegan Resources and Newmont have obtained from the Ghanaian state give these companies legal access to subterranean ore deposits, but they are only partially able to benefit from this. In both cases, we see that the companies still have to work out socio-spatial divisions of ore. Ribot and Peluso (2003) rightly stress that factors such as technology, knowledge, authority and identities play a key role in access mechanisms. Our approach to in-depth geopolitics applies their insights by connecting differences in technological capabilities and geological knowledge to the social field of localized politics and social organization. Companies use technology and geological knowledge to carry out their mining operations in regions where artisanal mining has a long history and strong associations with traditional forms of land use and ownership. Interestingly, the way in which artisanal miners can 'interrupt' state-capital alliances is due to their association with chiefs, who can still act as landowners.

The two cases show two different ways in which foreign mining companies appear to depend upon local political authorities. On the Keegan Resources exploration concession, chiefs play a major role. In the eyes of artisanal miners, the real authority is not the state-backed company but the chief. In working towards governance arrangements, Keegan Resources was very much aware of its dependence on this local authority. At one point the chief pleaded in favour of using machines to rework the zone dredged by Bonte. The company tried to curb this by proposing an alliance with the chief to restrict artisanal mining to local people and local techniques, thereby trying to confine access to those with property rights, yet using limited technologies. The tense situation that resulted increased the company's dependence on the chief to work out a form of cohabitation in which artisanal mining could be confined. In this case, foreign capital was unable to rely on the state, and was compelled instead to give weight to a specific category of citizens traditional chiefs. This example underscores how neoliberal shifts in governance where the state must retreat and give room to private actors - tend to strengthen rather than weaken the position of customary authorities (Geschiere 2007).

At Newmont's concession, where artisanal miners are tolerated in the artisanal mining site Sikamina, we similarly witnessed the central role of traditional authorities. Newmont's 'generosity' of 'leaving' this area to the artisanal miners was based on a pragmatic assessment of the social field in which the company operates: the company reckoned that chiefs, landowners and artisanal miners would team up if the company tried to 'empty' its concession by forcing them out. These strategic arrangements with artisanal miners are not part of the formal CSR policies. They came to the fore only when we delved into the geological details of Newmont's mining projects.

Teaming up with geologist Henk Gewald as co-researcher opened the doors to technical experts with surprisingly relevant information on the politics of cohabitation. Their knowledge about the underground positioning of ore (the 3D characteristics) informs strategies for controlling and maintaining access in the 2D social field of stakeholders. We see that Newmont could use the geological knowledge to determine strategies of 'access maintenance' for future gold production. Keegan found it more problematic to safeguard its access to ore, since that access depended on local authorities as mediators.

Our approach to in-depth geopolitics incorporates the 3D optics of companies, which allows for a more nuanced approach to issues of access and sovereignty 
than the insights offered by Ferguson in 'Seeing like an oil company' (2005). We have seen that concessions may seem to give a company a legal space to rule, but in practice this has to be exercised with care. Our analysis allows us to use Ferguson's (ibid.) distinction between 'usable' and 'unusable' space in more subtle and dynamic ways: the strategic interplay between usable and unusable spaces within concessions is best seen as an outcome of both struggles over access and strategies for cohabitation. In the case of Newmont, geological knowledge about the location of the water table in between two tables of ore bodies is used to decide how to control and maintain access: artisanal miners are 'given' the upper layer of the ore body, and the company knows - or presumes - that it will be able to mine what is underneath the water table sometime in the future. As a result of pressures in the social field and company-community strategies, the company decided to consider the upper layer of usable ore as unusable for its own extraction, 'leaving it' to artisanal miners. This is an interesting example of 'vertical reciprocity' (Adey 2010; Bridge 2013): Newmont deems the upper layer 'unusable', giving up ore in the present in order to govern and secure long-term social relations. Interestingly, we have seen that local people take a different view. They do not view the company as 'giving' them permission and access, as they are entitled to take what belongs to them in the first place. 'Local interruptions' (Emel et al. 2011) are first of all produced by differences in perception on access, legitimate authorities and property regimes.

In contrast, Keegan Resources was not in a position to strategically distinguish between usable and unusable, to 'give up' a specific part of the ore for the artisanal miners in order to safeguard another part for themselves. The geological 3D situation simply did not allow for this, since the company and the artisanal miners both wanted to work the same ore, and there was no barrier such as a water table that could be used to realize a split arrangement similar to Newmont's case. Keegan's only option to prevent artisanal miners from encroaching upon 'their' ore was to work out an arrangement with traditional chiefs.

\section{Conclusion}

We have seen that there is an extensive literature on the relationship between large-scale and small-scale mining. Too often, these two types of miners are portrayed as if they act in isolation from groups with other identities, be they state officials, local chiefs or farmers. Notions such as 'stakeholders' and 'companycommunity relations' (Ballard and Banks 2003) have inhibited proper analyses of the empirical processes of socio-politics on the ground. Only recently - and belatedly - have scholars such as Hilson and Geenen started to look into the nexus between mining and local politics. The link between traditional political authorities and mining is particularly pertinent in Ghana and resonates with the longstanding relationship between gold mining and political structures in Akan history. Wilks has shown how, since the fifteenth and sixteenth centuries, gold mining facilitated the accumulation of (unfree) labour in Akan societies, which in turn triggered an increase in agricultural production. This process of wealth creation was at the basis of the rise of Akan polities (Wilks 1977: 521). In colonial and postcolonial Ghana, chiefs have been recognized by state authorities as custodians of the land (Ubink 2007), but also as recipients of 
monies awarded by mineral development funds (MDFs) (Standing and Hilson 2013). This often causes chiefs to be in league with the state or mining companies, but our article shows that other alliances are possible as well. The connection between mining and political histories allows for identifications between local political authorities and artisanal miners, who see their work as a continuum of what their ancestors did (Hilson 2002b). Notions of autochthony allow artisanal miners, and local community members more broadly, to see the ore bodies as 'theirs'. Politics of belonging (Geschiere 2009) and shifting alliances between miners and authorities of different kinds thus deserve full attention in studies on mining.

This article contributes to such a focus by rethinking geopolitics (Cowen and Smith 2009) and access (Ribot and Peluso 2003). This allows us to situate mining operations in the local socio-political context in which they operate, as well as to recognize the relationships between different miners within broader social contexts of governance. The 'interruptions' we then witness provide interesting nuances on the state-capital alliances facilitated by 'subterranean sovereignty'; we see that local alliances between traditional authorities and miners can make companies vulnerable and dependent upon collaborations with locals. We also see that miners are recognized as politically valuable for their votes, and this may force state authorities to collaborate with miners 'against' companies. When analysing the politics of cohabitation in mining concessions and their surroundings, governance arrangements come to the fore based on complex (temporary) alliances and cleavages that are informed by socio-historical circumstances.

We have used the concept of 'in-depth geopolitics' to foreground how such governance arrangements depend not only on social situations, but also on the geological and technical aspects of mining. In that respect, the article develops further the recent analytical probing of articulations between the social and the natural. Studies on the materiality of minerals and mining infrastructure (Richardson and Weszkalnys 2014) show us that resource extraction depends on socionatures, on intricate entanglements of social and natural aspects. The notions of 'reserve' and 'resource' illustrate how the underground is variously classified according to such schemas of entanglement. Ore bodies are identified and their classification incorporates assessments of social, political, geological and technical capabilities to access ore. Knowledge of socionatures, and hence of the complex possibilities of accessing and extracting minerals, is of crucial importance in the governance strategies of companies.

\section{Acknowledgements}

We would like to thank the anonymous reviewers for their helpful comments and suggestions, and Henk Gewald, a professional geologist who proved to be invaluable as co-researcher during the fieldwork in Ghana. The authors have received financial support from the Treub Maatschappij and the Prins Bernhard Cultuurfonds to conduct fieldwork. 


\section{References}

Adey, P. (2010) Aerial Life: spaces, mobilities, affects. Oxford: Wiley-Blackwell.

AGA (2010) AngloGold Ashanti: sustainability report. Johannesburg: AngloGold Ashanti (AGA) <http://www.anglogoldashanti.com/en/Media/ Reports/Sustainability\%20Reports/AGA-sustainable-gold-2010.pdf>, accessed August 2014.

Andrew, J. S. (2003) 'Potential application of mediation to land use conflicts in small-scale mining', Journal of Cleaner Production 11 (2): 117-30.

Appel, H. (2012) 'Walls and white elephants: oil extraction, responsibility, and infrastructural violence in Equatorial Guinea', Ethnography 13 (4): 439-65.

Aubynn, A. (2006) "'Live and let live": the relationship between artisanal/smallscale and large-scale miners at Abosso Goldfields, Ghana' in G. Hilson (ed.), Small-scale Mining, Rural Subsistence and Poverty in West Africa. Rugby, UK: Practical Action Publishing.

Aubynn, A. (2009) 'Sustainable solution or a marriage of inconvenience? The coexistence of large-scale mining and artisanal and small-scale mining on the Abosso Goldfields concession in Western Ghana', Resources Policy 34: 64-70.

Baba, S. and E. Raufflet (2014) 'Managing relational legacies: lessons from British Columbia, Canada', Administrative Sciences 4 (1): 15-34.

Ballard, C. and G. Banks (2003) 'Resource wars: the anthropology of mining', Annual Review of Anthropology 32: 287-313.

Bridge, G. (2009) 'The hole world: spaces and scales of extraction', New Geographies 2: 43-8.

Bridge, G. (2013) 'Territory, now in 3D!', Political Geography 34: 55-7.

Campbell, B. (2011) 'Canadian mining in Africa: "do as you please" approach comes at high cost', Canadian Dimension 45 (1): 28-32.

Ceuppens, B. and P. Geschiere (2005) 'Autochthony: local or global? New modes in the struggle over citizenship and belonging in Africa and Europe', Апnиal Review of Anthropology 34: 385-408.

Cowen, D. and N. Smith (2009) 'After geopolitics? From the geopolitical social to geoeconomics', Antipode 41 (1): 22-48.

Dumett, R. E. (1998) El Dorado in West Africa. Athens OH and Oxford: Ohio University Press and James Currey.

Emel, J., M. T. Huber and M. H. Makene (2011) 'Extracting sovereignty: capital, territory, and gold mining in Tanzania', Political Geography 30: 70-9.

Ferguson, J. (2005) 'Seeing like an oil company: space, security and global capital in neoliberal Africa', American Anthropologists 107 (3): 377-82.

Ferry, E. E. (2005) Not Ours Alone: patrimony, value and collectivity in contemporary Mexico. New York NY: Columbia University Press.

Ferry, E. E. and M. Limbert (2008) Timely Assets: the politics of resources and their temporalities. Santa Fe NM: School of Advanced Research Press.

Firmin-Sellers, K. (1995) 'The politics of property rights', American Political Science Review 89 (4): 867-81.

Geenen, S. (2015) 'Hybrid governance in mining concessions in Ghana'. Field report, 6 November <http://sarageenen.net/?p=337>, accessed 8 March 2016. 
Gellert, P. (2005) 'For a sociology of socionature: ontology and a commoditybased approach' in P. Ciccantell, G. Seidman and D. Smith (eds), Nature, Raw Materials and Political Economy. The Hague: Elsevier Science/JAI Press.

Geschiere, P. (2007) 'Epilogue. "Seeing like a state" in Africa: high modernism, legibility and community', African Studies 66 (1): 129-34.

Geschiere, P. (2009) The Perils of Belonging: autochthony, citizenship, and exclusion in Africa and Europe. Chicago IL: Chicago University Press.

Gewald, H. (2010) 'Gold as a geological item' in C. Panella (ed.), Worlds of Debts: gold mining in West Africa as an interdisciplinary field of study. Amsterdam: Rozenberg Publishers.

Griffis, R. J., K. Barning, F. L. Agezo and F. K. Akosah (2002) Gold Deposits of Ghana. Accra: Minerals Commission Ghana.

Hilson, G. (2002a) 'An overview of land use conflicts in mining communities', Land Use Policy 19 (1): 65-73.

Hilson, G. (2002b) 'Land use competition between small- and large-scale miners: a case study of Ghana', Land Use Policy 19 (2): 149-56.

Hilson, G. (2007) 'Championing the rhetoric: corporate social responsibility in the Ghanaian mining sector', Greener Management International 53: 43-56.

Hilson, G. (2011) 'Inherited commitments: do changes in ownership affect corporate social responsibility (CSR) at African gold mines?', African Journal of Business Management 5 (27): 10921-39.

Hilson, G. and N. Yakovleva (2007) 'Strained relations: a critical analysis of the mining conflict in Prestea, Ghana', Political Geography 26 (1): 98-119.

Hilson, G., N. Yakovleva and S. M. Banchirigah (2007) "'To move or not to move": reflections on the resettlement of artisanal miners in the Western Region of Ghana', African Affairs 106 (424): 413-36.

Ho, K. (2009) Liquidated: an ethnography of Wall Street. Durham NC and London: Duke University Press.

Jennings, N. S. (1994) 'Small-scale mining: a labour and social perspective' in A. J. Ghose (ed.), Small-scale Mining: a global overview. Rotterdam: A. A. Balkema.

Kapelus, P. (2009) 'Appendix 1: narrative report 1 D Ahafo mine, Ghana' in Community Relationships Review: global summary report. Accra: Newmont Ghana Gold Limited.

Latour, B. (1987) Science in Action: how to follow scientists and engineers through society. Boston MA: Harvard University Press.

Lentz, C. (2006) 'Land rights and the politics of belonging in West Africa: an introduction' in R. Kuba and C. Lentz (eds), Land and the Politics of Belonging in West Africa. Leiden: Brill.

Luning, S. W. J. (2014) 'The future of artisanal miners from a large-scale perspective: from valued pathfinders to disposable illegals?', Futures 62 (A): $67-74$.

Luning, S. W. J., J. Jansen and C. Panella (2014) 'The mise en valeur of the gold mines in the Haut-Niger, 1918-1939', French Colonial History 15: 67-86.

MacEachern, S. (2010) 'Seeing like an oil company's CHM programme: Exxon and archaeology on the Chad Export Project', Journal of Social Archaeology 10 (3): 347-66.

Maurer, B. (2005) Mutual Life, Limited: Islamic banking, alternative currencies, lateral reason. Princeton NJ: Princeton University Press. 
Newmont (2005) Environmental and Social Impact Assessment: Ahafo South Project. Accra: Newmont Ghana Gold Limited.

Newmont (2009) Community Relationships Review: global summary report. Accra: Newmont Ghana Gold Limited <http://s1.q4cdn.com/259923520/files/doc downloads/crr/CRR-Global-Summary-Report-and-Appendices-English.pdf $>$, accessed 15 July 2014.

Prno, J. and D. S. Slocombe (2012) 'Exploring the origins of "social license to operate" in the mining sector: perspectives from governance and sustainability theories', Resources Policy 37 (3): 346-57.

Ribot, J. C. and N. L. Peluso (2003) 'A theory of access', Rural Sociology 68 (2): 153-81.

Richardson, T. and G. Weszkalnys (2014) 'Resource materialities: new anthropological perspectives on natural resource environments. Introduction', Anthropological Quarterly 87 (1): 5-30.

Scott, J. (1998) Seeing Like a State: how certain schemes to improve the human condition have failed. New Haven CT: Yale University Press.

Sikor, T. and L. Lund (2009) 'Access and property: a question of power and authority', Development and Change 40 (1): 1-22.

Sosa, I. (2012) 'Responsible investment case studies: Newmont and Goldcorp' in J. Sagebien and N. M. Lindsay (eds), Governance Ecosystems: CSR in the Latin American mining sector. London: Palgrave.

Standing, A. and G. Hilson (2013) 'Distributing mining wealth to communities in Ghana: addressing problems of elite capture and political corruption'. U4 Issue 5. Bergen: U4 Anti-Corruption Resource Centre.

Swyngedouw, E. (1996) 'The city as a hybrid: on nature, society and cyborg urbanization', Capitalism, Nature, Socialism 7 (2): 65-80.

Swyngedouw, E. (2004) Social Power and the Urbanization of Water. Oxford: Oxford University Press.

Teschner, B. (2013) 'How you start matters: a comparison of Gold Fields' Tarkwa and Damang mines and their divergent relationships with local small-scale miners in Ghana', Resources Policy 38: 332-40.

Tschakert, P. (2009) 'Digging deep for justice: a radical re-imagination of the artisanal gold mining sector in Ghana', Antipode 41 (4): 706-40.

Tsing, A. L. (2005) Friction: an ethnography of global connection. Princeton NJ: Princeton University Press.

Ubink, J. (2007) 'Traditional authority revisited: popular perceptions of chiefs and chieftaincy in peri-urban Kumasi, Ghana', Journal of Legal Pluralism 55: 123-61.

Welker, M. (2014) Enacting the Corporation: an American mining firm in postauthoritarian Indonesia. Berkeley and Los Angeles CA: University of California Press.

Wilks, I. (1977) 'Land, labour, capital and the forest kingdom of Asante: a model of early change' in J. Friedman and M. J. Rowlands (eds), The Evolution of Social Systems. London: Duckworth.

Zaloom, C. (2006) Out of the Pits: traders and technology from Chicago to London. Chicago IL: University of Chicago Press. 


\begin{abstract}
Studies of articulations between large- and small-scale mining have overlooked the subterranean dimension of extraction and ignored how mining companies and artisanal miners cohabit in places with long histories of small-scale mining and are affected by their different capacities to access specific mineral deposits. Drawing on a study of two gold concessions in Ghana, this article focuses on three factors that influence modalities of governing access to gold in such sites: the stage of a mining operation, the local socio-political context, and the characteristics of the subterranean structure. We call the combination and interplay of these factors 'in-depth geopolitics'. The article shows how this interplay affects the strategies used by both large- and small-scale miners to work out arrangements of cohabitation and ways of governing access, control and maintenance to gold in spatial settings where both types of gold mining occur side by side. By tracing ethnographically the variations of 'in-depth geopolitics', this article critically engages with ideas of subterranean sovereignty, mining enclaves, statecompany-community relations, and the socio-spatial characteristics of mining concessions.
\end{abstract}

\title{
Résumé
}

Les études sur les articulations entre les activités minières à grande et à petite échelle ont occulté la dimension souterraine de l'extraction et ignoré la manière dont les sociétés minières et les artisans mineurs cohabitent dans des lieux qui ont une longue histoire d'exploitation minière à petite échelle et sont affectés par différentes capacités à accéder aux gisements. S'appuyant sur une étude de deux concessions aurifères au Ghana, cet article traite de trois facteurs qui influencent les modalités de gouvernance d'accès à l'or sur ces sites : le stade d'exploitation minière, le contexte sociopolitique local et les caractéristiques de structure souterraine. Les auteurs appellent " géopolitique en profondeur » la combinaison et l'interaction de ces facteurs. L'article montre comment cette interaction affecte les stratégies utilisées par les mineurs à grande et à petite échelle pour trouver des modes de cohabitation et de gouvernance d'accès, de contrôle et de maintenance de l'or dans les espaces où se côtoient ces deux types d'exploitation aurifère. En faisant un tracé ethnographique des variations de " géopolitique en profondeur », cet article traite de manière critique des idées de souveraineté souterraine, d'enclaves minières, des relations État/entreprise/communauté et des caractéristiques sociospatiales des concessions minières. 